\title{
Effects of HAART in the nutritional status of children and adolescents infected by HIV in Brazil: a systematic review
}

\author{
Efeitos da HAART no estado nutricional de crianças e adolescentes \\ infectados pelo HIV no Brasil: uma revisão sistemática
}

Lucia Helena Almeida Gratão (https://orcid.org/0000-0001-5817-5784) ${ }^{1}$

Guilherme Nobre Lima do Nascimento (https://orcid.org/0000-0003-4185-0872) ${ }^{2}$

Renata Junqueira Pereira (https://orcid.org/0000-0001-9487-4013) ${ }^{2}$

${ }^{1}$ Faculdade de Medicina, Universidade Federal de Minas Gerais. Av. Prof Alfredo Balena 190, Santa Efigênia. 30130-100 Belo Horizonte MG Brasil. luciagratao@gmail.com ${ }^{2}$ Laboratório de Ciências Básicas e da Saúde, Curso de Nutrição, Universidade Federal do Tocantins. Palmas Tocantins Brazil.

\begin{abstract}
The verification of factors associated with growth, body composition and nutritional and nutritional aspects after HIV infection in children or adolescents in Brazil is fundamental for progress in this area. We selected articles published until 2018, available on the platforms PubMed and Lilacs, using the keywords The following descriptors and their associations were used, extracted from MeSH: "Children", "Adolescent", "Anthropometry", "Nutritional Assessment", "HIV", "Brazil" adding the filter "and" for advanced searches. A total of 1,450 articles were found, and after selection and full reading, 19 were selected. The studies agreed that children and adolescents living with HIV present or may present alterations in bone metabolism, lipid metabolism and body composition due to infection or associated with therapy. Significant differences were observed in weight and height in infected infants compared to uninfected infants. The evaluation and monitoring of diet quality, as well as serum micronutrient monitoring, are fundamental to guarantee the clinical and treatment conditions of these patients, as well as to prevent disorders due to low nutrient intakes.
\end{abstract}

Key words HIV Infections, Acquired immunodeficiency syndrome, Child nutrition disorders, Adolescent nutritional physiological phenomena
Resumo A verificação de fatores associados ao crescimento, composição corporal e aspectos alimentares e nutricionais, após a infecção pelo HIV em crianças ou adolescentes no Brasil é fundamental para avanços nesta área. Foram selecionados artigos publicados até 2018, disponibilizados nas plataformas PubMed e Lilacs, extraídas do MeSH: "Children", "Adolescent", "Anthropometry", "Nutritional Assessment", "HIV", "Brazil" adicionadas do filtro "and" para as pesquisas. Foram encontrados 1.450 artigos e após seleção e leitura integral foram selecionados 19. Os estudos concordaram que crianças e adolescentes vivendo com HIV apresentam ou podem apresentar alterações no metabolismo ósseo, de lipídeos e na composição corporal devido à infecção ou associadas à terapia. Observou-se diferença significativa do peso e estatura em crianças infectadas em relação às não infectadas. Percebe-se que a avaliação e o monitoramento da qualidade da dieta, bem como o acompanhamento sérico de micronutrientes, são fundamentais para garantir as condições clínicas e de tratamento destes pacientes, bem como para prevenir desordens por baixo consumo de nutrientes.

Palavras-chave Infecções por HIV, Sindrome de imunodeficiência adquirida, Transtornos da nutrição infantil, Fenômenos fisiológicos da nutrição do adolescente 


\section{Introduction}

In Brazil, the first cases of HIV in children were recorded in 1983, due to infection from blood or contaminated derivatives during transfusions. In August 1998, there were 140,362 reported cases, the majority of which were infected by vertical transmission ${ }^{1}$.

The mortality of HIV-infected children and adolescents as well as vertical transmission infection tended to decrease in recent epidemiological reports $^{2,3}$ after the introduction of Highly Active Antiretroviral Therapy (HAART) ${ }^{4}$. This therapy has reduced the incidence of opportunistic diseases ${ }^{5}$, increased time and quality of life, and improvements in neural development and linear growth $^{6}$.

However, there are numerous adverse effects associated with HAART, especially Protease Inhibitors (PIs) such as Stavudine (d4T), Tenofovir (TDF) and Ritonavir (RTV). These are related to lipodystrophy, insulin resistance, metabolic and body composition changes, such as changes in bone mass in children and adolescents ${ }^{7}$. This is intensified when the individual is exposed to a long period of therapy, as occurs in those infected by vertical transmission, which in many cases already begin exposure to anti-retrovirals in intrauterine life ${ }^{6,8}$.

Unhealthy eating habits may intensify the undesirable effects of antiretroviral therapy, especially associated with hyperglycemia, dyslipidemia and increased risk for cardiovascular diseases ${ }^{9,10}$. Tanaka et al. ${ }^{11}$ found that HIV-infected adolescents had the same eating behavior as uninfected adolescents, with a high prevalence of sugar, saturated fat and sodium and a low daily intake of whole grains and fruits, increasing the chances of dyslipidemia and risk for cardiovascular disorders.

In view of the above, it is essential the nutritional monitoring of HIV-infected children and adolescents in order to prevent or to avoid the progression of disorders associated with the use of HAART, thus providing more effective pharmacological treatment ${ }^{11,12}$.

Thus, the objective of this study was to review the original Brazilian studies that address nutritional aspects in children or adolescents infected with HIV in order to verify the risk factors associated with growth, body composition and food aspects after infection.

\section{Methods}

A systematic review of the literature was carried out in different scientific databases during the month of april 2019, with the objective of reviewing and grouping the results of original papers published in scientific journals that addressed the nutritional aspects of children and/ or adolescents infected by HIV in Brazil. To determine the research question, the PECO (Populations, Exposure, Comparator and Outcome) methodology was used.

We used articles available on the platforms National Library of Medicine's - National Intitutes of Health (PubMed) and Latin American and Caribbean Literature in Health (Lilacs). The following descriptors and their associations were used, extracted from MeSH: "Children", "Adolescent", "Anthropometry", "Nutritional Assessment", "HIV", "Brazil" adding the filter "and" for advanced searches.

Articles were found and included from 2000 to 2018, written in English and Portuguese vernaculars, and the following inclusion criteria were applied: (1) original articles, (2) samples composed by Brazilians, (3) only works developed with humans (Figure 1). We excluded studies that, even using Brazilian samples, had compared and used population samples from other countries.

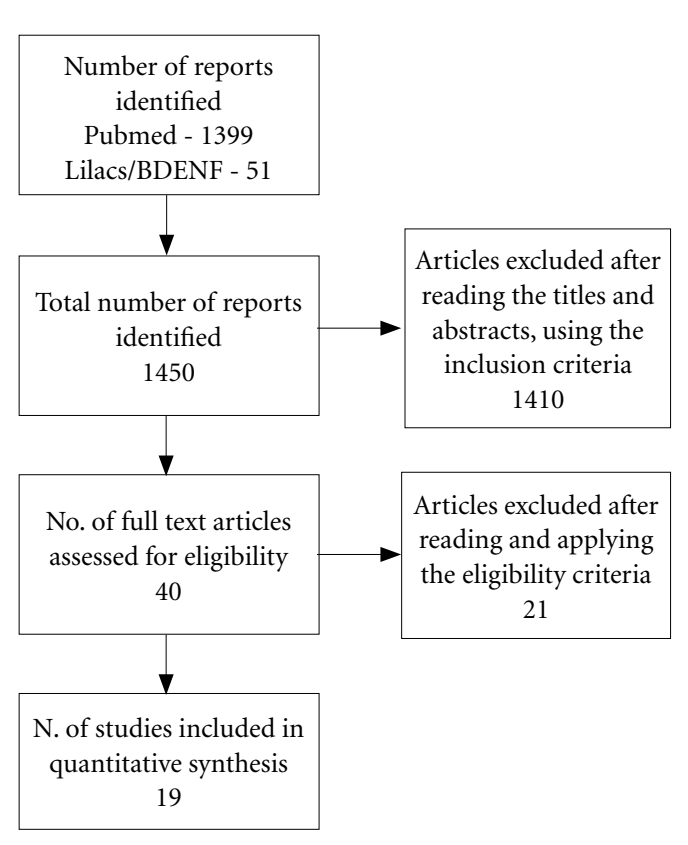

Figure 1. Flowchart of the review process. 
The study was divided into the following steps: i) search of articles in the databases, ii) screening by reading titles and abstracts, iii) reading the study in its entirety. The third step was done by two different researchers to decide which items were eligible for discussion.

In the first stage of the study 1450 articles were found, being 1399 from Pubmed and 51 from Lilacs/BDENF. Each one had their titles and abstracts read to see if they could be included in the sample. A total of 40 articles were selected for the second stage of the study, which consisted of reading all the papers.

After completing the reading, 19 articles were selected that were relevant to the proposed theme. These studies were divided into four main themes, according to the subject matter. (1) Body Composition and Bone Mineral Density (BMD) in children and adolescents infected with HIV; (2) Body composition and lipodystrophy syndrome in HIV-infected children and adolescents; (3) Anthropometry of HIV-infected children and adolescents; and (4) Diet Quality in children and adolescents infected with HIV.

\section{Results}

All the articles selected for the theme $(1)^{7,8,13,14}$ (Chart 1) agreed that children who lives with HIV present or may present alterations in bone metabolism, whether due to infection or associated with HAART.

They also agree that adequate ingestion and serum micronutrient monitoring can prevent disorders in bone metabolism and benefit children or adolescents who already have some type of impairment in this tissue ${ }^{8,13,14}$. Although Lima et $\mathrm{al}^{7}$ found no significant relationship between low BMD and calcium intake.

Four studies were selected to compose the theme (2) $)^{9,10,15,16}$ (Chart 2) and in the four were found significant changes in body composition in the studied individuals. They also found association of HAART with dyslipidemias in the populations studied. No glycemic changes were reported in any of the studies.

Regarding the theme (3) (Chart 3), there was a significant difference in weight and height in HIV-infected children in relation to uninfected children ${ }^{1}$. The articles ${ }^{1,4,6,17-23}$, found for this theme have affirmed in their conclusions that the monitoring of the nutritional status of children and adolescents can minimize clinical and metabolic alterations, being determinant for the evaluation of the risk of disease progression and, consequently, successful treatment.
However, Contri et al. ${ }^{6}$ did not find in their study associations between improvement of anthropometric measures, body composition and food intake and the use of IP. On the other hand, Diniz et al. ${ }^{21}$ reported that the use of this pharmacological class resulted in a significant increase in weight/age and height/age z-scores.

Only one article ${ }^{11}$ was included on the theme 4 (Chart 4). Other studies approached and used strategies to evaluate dietary intake, but they did not integrate this group, since its objectives did not broadly contemplate the theme. Tanaka et al. ${ }^{11}$ found a similar dietary pattern among HIV-infected adolescents and uninfected children, and stressed the importance of dietary monitoring in preventing the development of cardiovascular diseases and other chronic diseases.

\section{Discussion}

The research of nutritional aspects in all population groups has its importance widely diffused by all organs and associations related to health, regardless of the area of professional activity, especially for children and adolescents. This is due to the already well established positive relationship between healthy eating habits, quality of life and disease prevention ${ }^{24,25}$.

However, despite the knowledge that HIV infection and the use of HAART may interfere negatively with human metabolism and body composition, the use of nutritional strategies is still incipient ${ }^{26}$.

Raiten et al..$^{12}$ argue that HAART is essential for prolonging and disrupting HIV / AIDS transmission; however, adequate nutrition and nutritional status are fundamental to human health, and it is indispensable to associate both care to a better prognosis in adolescents and adults 5 .

Cardoso et al. ${ }^{5}$ also warn that children and adolescents infected with HIV, through HAART, are living longer and reaching adulthood, despite the increased chances of Non-communicable Chronic Diseases (NCD) that HAART imposes, but can be avoided with dietary counseling and / or treatment ${ }^{9}$.

\section{Anthropometry}

Children and adolescents infected with HIV have a lower weight, height, head circumference and anthropometric indices (weight-for-age, height-for-age, BMI-for-age and weight-forheight) than non-infected children, especially during first years of life 5,27 . 
Chart 1. Synthesis of articles on body composition and bone mineral density (BMD) of HIV-infected children and adolescents (Theme 1).

\begin{tabular}{|c|c|c|c|c|}
\hline Author, year & Target group & Study design & Diagnostic Methods & Main results \\
\hline $\begin{array}{l}\text { Carmo et al., } \\
2017^{13} \text {. }\end{array}$ & $\begin{array}{l}58 \text { children and } \\
\text { adolescents } \\
(35 \text { female, } 23 \\
\text { male), aged } \\
\text { between } 5 \text { and } \\
20 \text { years-old. }\end{array}$ & Cohort & $\begin{array}{l}\text { Biochemical } \\
\text { examinations, } \\
\text { clinical data, DXA, } \\
\text { degree of sexual } \\
\text { maturation (Tanner), } \\
\text { food frequency } \\
\text { questionnaire. }\end{array}$ & $\begin{array}{l}\text { Patients living with HIV are at } \\
\text { increased risk for BMD changes. } \\
\text { Lower serum levels of vitamin D in } \\
\text { HIV-infected children. }\end{array}$ \\
\hline $\begin{array}{l}\text { Palchetti, et } \\
\text { al. } 2015^{8} \text {. }\end{array}$ & $\begin{array}{l}35 \text { children } \\
\text { ( } 18 \text { female, } 17 \\
\text { male), aged } 7 \text { to } \\
12 \text { years-old. }\end{array}$ & Cohort & $\begin{array}{l}\text { Weight, height, } \\
\text { BMI, weight by age } \\
\text { (WHO, 2007), DXA, } \\
\text { biochemical tests, 24h } \\
\text { recall of food intake, } \\
\text { degree of sexual } \\
\text { maturation (Tanner). }\end{array}$ & $\begin{array}{l}\text { Bone mass involvement in children } \\
\text { living with HIV. Adequate intake } \\
\text { of calcium and fat helps in the } \\
\text { accumulation of bone mass. }\end{array}$ \\
\hline $\begin{array}{l}\text { Lima et al., } \\
2013^{7} \text {. }\end{array}$ & $\begin{array}{l}48 \text { children and } \\
\text { adolescents } \\
\text { ( } 24 \text { females, } 24 \\
\text { males), aged } \\
\text { between } 7 \text { and } \\
17 \text { years-old. }\end{array}$ & $\begin{array}{l}\text { Cross- } \\
\text { sectional }\end{array}$ & $\begin{array}{l}\text { Height, weight, } \\
\text { anthropometric indices } \\
\text { (WHO, 2007), DXA, } \\
\text { clinical data, wrist and } \\
\text { left hand radiographs, } \\
\text { physical activity level } \\
\text { (pedometer), food } \\
\text { consumption frequency } \\
\text { questionnaire. }\end{array}$ & $\begin{array}{l}\text { Delay in skeletal maturation. } \\
\text { Inadequate level of physical } \\
\text { activity. Inadequate intake of } \\
\text { calcium. DMO significantly lower } \\
\text { in the group that used protease } \\
\text { inhibitors. No significant difference } \\
\text { was found between calcium intake, } \\
\text { physical activity level and bone } \\
\text { mass. }\end{array}$ \\
\hline $\begin{array}{l}\text { Schtscherbyna } \\
\text { et al., } 2012^{14} \text {. }\end{array}$ & $\begin{array}{l}74 \text { adolescents } \\
(41 \text { female, } 33 \\
\text { male), with } \\
\text { mean age of } \\
17.3 \text { years-old. }\end{array}$ & Cohort & $\begin{array}{l}\text { Biochemical tests, } \\
\text { DXA, weight, height, } \\
\text { BMI, degree of sexual } \\
\text { maturation (Tanner), } \\
\text { 24h recall of food } \\
\text { consumption. }\end{array}$ & $\begin{array}{l}\text { Low BMD in the study population. } \\
\text { Positive relationship between use } \\
\text { of Tenofovir and low bone mass. } \\
\text { Positive relationship between body } \\
\text { composition, weight, BMI, body fat } \\
\text { and BMD. Low intakes of vitamin } \\
\text { D and calcium among adolescents } \\
\text { living with HIV. }\end{array}$ \\
\hline
\end{tabular}

This difference is influenced by multiple factors such as high rates of hospitalization, AIDS and the incidence of opportunistic diseases; the intrauterine and postnatal exposures to HAART; the low socioeconomic status of the family and nutritional deficiencies ${ }^{5,21,22}$. Other factors associated with failure to thrive in HIV-infected children include abnormal thyroid hormone secretion and growth, changes in lipid metabolism, increased energy needs and resting energy expenditure ${ }^{21}$.

Some studies have observed that the severity of AIDS manifestation is directly related to the nutritional status of the child or adolescent, and malnutrition is a risk factor for death in this group $^{5,23}$.

Other results demonstrated that the initiation of HAART promotes a significant increase in weight and height in infected children, and anthropometric data can be used as indicators of quality and efficacy of therapy ${ }^{5}$. Thus, the identification of abnormal weight gain and/or insufficient growth alert the reassessment of the pharmacological and nutritional intervention adopted $^{1,21,22}$.

Anthropometry and anthropometric indices are non-invasive and low-cost alternatives that allow monitoring and nutritional diagnosis, mainly of malnutrition, in the early stages of therapy, being sensitive predictors of the risk of disease progression in children, it is indispensable in clinical practice during the care of children and adolescents infected with HIV 22,28.

\section{Body composition}

It is well established in the literature that HIV-infected children and adolescents may have 
Chart 2. Synthesis of articles on body composition and lipodystrophy syndrome in children and adolescents infected with HIV (Theme 2).

\begin{tabular}{|c|c|c|c|c|}
\hline $\begin{array}{c}\text { Author, } \\
\text { year }\end{array}$ & Target group & $\begin{array}{l}\text { Study } \\
\text { design }\end{array}$ & Diagnostic Methods & Main results \\
\hline $\begin{array}{l}\text { Papi et al., } \\
2014^{10} .\end{array}$ & $\begin{array}{l}90 \text { children ( } 52 \\
\text { female, } 38 \text { male), } \\
\text { with age from } 3 \\
\text { to } 16 \text { years-old. }\end{array}$ & $\begin{array}{l}\text { Cross- } \\
\text { sectional }\end{array}$ & $\begin{array}{l}\text { Weight, height, skinfolds (triceps, } \\
\text { subscapular and brachial), } \\
\text { waist and arm circumference, } \\
\text { anthropometric indices (NCHS, } \\
\text { 1977), biochemical tests. }\end{array}$ & $\begin{array}{l}\text { Lipodystrophy in } 51 \% \text { of } \\
\text { the sample. Low intake of } \\
\text { vegetables and fruits was } \\
\text { associated with dyslipidemia. } \\
\text { Inadequate intake of sugar } \\
\text { and fat. Lopinavir and } \\
\text { ritonavir were associated } \\
\text { with dyslipidemia. } \\
\end{array}$ \\
\hline $\begin{array}{l}\text { Palchetti et } \\
\text { al., } 2013^{15} \text {. }\end{array}$ & $\begin{array}{l}52 \text { prepubertal } \\
\text { children, aged } 7 \\
\text { to } 12 \text { years old of } \\
\text { both sexes. }\end{array}$ & $\begin{array}{l}\text { Cross- } \\
\text { sectional }\end{array}$ & $\begin{array}{l}\text { Degree of sexual maturation } \\
\text { (Tanner diagrams), weight, } \\
\text { height, BMI, skinfolds } \\
\text { (subscapular, suprailiac, biceps, } \\
\text { triceps), circumferences, trunk } \\
\text { to arm ratio, DEXA, biochemical } \\
\text { tests. }\end{array}$ & $\begin{array}{l}\text { Clinical lipodystrophy } \\
\text { was identified in } 27,5 \% \\
\text { of the sample. } 33(82.5 \%) \\
\text { were eutrophic, } 6(15 \%) \\
\text { overweight/obese and } 34 \\
\text { ( } 85 \%) \text { showed proper height. } \\
\text { Dyslipidemia was found in } \\
70 \% \text { of children. The trunk } \\
\text { to arm ratio showed a strong } \\
\text { association with the presence } \\
\text { of lipodystrophy. }\end{array}$ \\
\hline $\begin{array}{l}\text { Werner et } \\
\text { al., } 2010^{9} .\end{array}$ & $\begin{array}{l}43 \text { ( } 24 \text { children } \\
\text { and } 19 \\
\text { adolescents) aged } \\
2 \text { to } 16 \text { years-old } \\
\text { of both sexes. }\end{array}$ & \begin{tabular}{|l|} 
Cross- \\
sectional \\
descriptive
\end{tabular} & $\begin{array}{l}\text { Biochemical tests, degree of sexual } \\
\text { maturation (Tanner diagrams), } \\
\text { BMI, subscapular and triceps } \\
\text { skinfold, clinical evaluation, } \\
\text { family history, physical activity } \\
\text { level, semi-quantitative food } \\
\text { frequency questionnaire. }\end{array}$ & $\begin{array}{l}\text { Lipid change by } 88.3 \% \text {. Body } \\
\text { shape in } 13.9 \% \text {. Adequate } \\
\text { nutritional status in } 81.3 \% \text {. } \\
\text { Cholesterol intake above } \\
\text { recommended. }\end{array}$ \\
\hline $\begin{array}{l}\text { Sarni et al., } \\
2009^{16} \text {. }\end{array}$ & $\begin{array}{l}30 \text { children and } \\
\text { adolescents with } \\
\text { age between } 4 \\
\text { and } 14 \text { years-old } \\
\text { of both sexes } \\
\text { (14 male and } 16 \\
\text { female). }\end{array}$ & $\begin{array}{l}\text { Cross- } \\
\text { sectional }\end{array}$ & $\begin{array}{l}\text { Weight, height, biochemical } \\
\text { tests, degree of sexual } \\
\text { maturation (Tanner diagrams), } \\
\text { anthropometric indices (WHO, } \\
\text { 1995), physical examination by } \\
\text { qualified professional. }\end{array}$ & $\begin{array}{l}\text { Dyslipidemia was found } \\
\text { in } 60 \% \text { of children and } \\
\text { adolescents evaluated. } \\
\text { Clinical lipodystrophy was } \\
\text { observed in } 53.3 \% \text { of sample, } \\
\text { showing a relationship with } \\
\text { the antiretroviral regimen } \\
\text { employed. }\end{array}$ \\
\hline
\end{tabular}

a compromised bone mineral density and content, both for the use of HAART and for factors associated with HIV infection ${ }^{7,8}$. The changes are more notable in more vascularized areas of the bone, such as the metaphysis of the long bones ${ }^{29}$.

Infection of bone cells by the virus and host response may alter tissue metabolism, compromising gains in bone size, mass, and strength ${ }^{7,14}$. Aids, as a chronic disease, predisposes to the production of pro-inflammatory cytokines (IL-1, 6, 17 and TNF- ), which can intensify the activity of osteoclasts and suppress the activity of osteoblasts, causing apoptosis. In addition, the virus can stimulate the activation receptor ligand of nuclear factor kappa B, which also promotes osteoclastogenic stimulation, resulting in dis- equilibrium of bone remodeling and increased resorption $^{8,14}$.

In vitro analyzes they demonstrated that HIV-specific proteins interfere with mesenchymal differentiation in osteoblasts and reduce the secretion of regulatory molecules and transcription of activity factors in osteoblasts. In addition, HIV infection increases the production of IGF-1 and stimulates the formation and activity of osteoclasts, reducing bone mass ${ }^{7,14}$.

Among the antiretrovirals, Tenofovir (TDF) stands out, which has been associated with renal and bone toxicity, since it promotes the reduction of phosphate reabsorption, leading to hypophosphatemia and consequent reduction of bone mineralization $^{13-14}$. 
Chart 3. Synthesis of articles on anthropometry in HIV-infected children and adolescents (Theme 3).

\begin{tabular}{|c|c|c|c|c|}
\hline Author, year & Target group & Study design & Diagnostic Methods & Main results \\
\hline $\begin{array}{l}\text { Lima et al., } \\
2018^{17} \text {. }\end{array}$ & $\begin{array}{l}65 \text { children and } \\
\text { adolescents between } \\
8.0 \text { and } 15.2 \text { years of } \\
\text { age ( } 30 \text { male and } 35 \\
\text { female) }\end{array}$ & $\begin{array}{l}\text { Cross- } \\
\text { sectional }\end{array}$ & $\begin{array}{l}\text { DXA, weight, height, BMI, } \\
\text { biochemical tests. }\end{array}$ & $\begin{array}{l}\text { The z-score of stature for age lower } \\
\text { and profiles potentially associated } \\
\text { with premature atherosclerosis due } \\
\text { to inflammation, elevated IMTc, } \\
\text { higher atherogenic lipid levels, and } \\
\text { higher blood glucose levels. }\end{array}$ \\
\hline $\begin{array}{l}\text { Schtscherbyna } \\
\text { et al., } 2016^{18} \text {. }\end{array}$ & $\begin{array}{l}65 \text { adolescents and } \\
\text { young adults with } \\
17.6 \pm 2 \text { years old of } \\
\text { both genders. }\end{array}$ & $\begin{array}{l}\text { Cross- } \\
\text { sectional }\end{array}$ & $\begin{array}{l}\text { Weight, height, BMI, degree } \\
\text { of sexual maturation (Tanner } \\
\text { diagrams) anthropometric } \\
\text { indices (WHO, 2007), } \\
\text { dietary assessment was } \\
\text { based on a 24-h recall, } \\
\text { International Physical } \\
\text { Activity Questionnaire } \\
\text { (IPAQ), biochemical tests. }\end{array}$ & $\begin{array}{l}\text { Found } 29.2 \% \text { were Vitamin } \\
\mathrm{D} \text { insufficiency and } 23,1 \% \text { of } \\
\text { adolescents were severe thinness or } \\
\text { thinness. }\end{array}$ \\
\hline $\begin{array}{l}\text { Pugliese et al., } \\
2014^{19} \text {. }\end{array}$ & $\begin{array}{l}83 \text { prepubertal } \\
\text { children of both } \\
\text { genders. }\end{array}$ & $\begin{array}{l}\text { Cross- } \\
\text { sectional }\end{array}$ & $\begin{array}{l}\text { Weight, height, } \\
\text { anthropometric indices } \\
\text { (WHO, 2007), clinical } \\
\text { evaluations, biochemical } \\
\text { tests, 24h recall of food } \\
\text { consumption. }\end{array}$ & $\begin{array}{l}\text { HIV-infected children had lower } \\
\text { Z-score height / age and high } \\
\text { prevalence of short stature (11.8\%). } \\
\text { Low levels of selenium and high } \\
\text { levels of copper were found in } \\
\text { biochemical tests. }\end{array}$ \\
\hline $\begin{array}{l}\text { Bassichetto et } \\
\text { al., } 2013^{20} \text {. }\end{array}$ & $\begin{array}{l}142[71 \text { children } \\
(<10 \text { years old }), \\
71 \text { adolescents }(10 \\
\text { to } 19 \text { years old })] \text { of } \\
\text { both genders. }\end{array}$ & $\begin{array}{l}\text { Cross- } \\
\text { sectional }\end{array}$ & $\begin{array}{l}\text { Weight }(\mathrm{kg}) \text {, length and } \\
\text { height }(\mathrm{cm}) \text {, anthropometric } \\
\text { indices }(\mathrm{WHO}, 2007) .\end{array}$ & $\begin{array}{l}\text { Growth among children and } \\
\text { adolescents was similar to patterns } \\
\text { of growth in the general population, } \\
\text { with an increase in weight and height } \\
\text { with age. }\end{array}$ \\
\hline $\begin{array}{l}\text { Contri et al., } \\
2011^{6} \text {. }\end{array}$ & $\begin{array}{l}59 \text { children and } \\
\text { adolescents of both } \\
\text { sexes, aged between } \\
3 \text { and } 17 \text { years old. }\end{array}$ & $\begin{array}{l}\text { Descriptive } \\
\text { longitudinal }\end{array}$ & $\begin{array}{l}\text { Weight, height, } \\
\text { anthropometric indices } \\
\text { (WHO, 2007), waist } \\
\text { circumference, arm } \\
\text { circumference, subscapular } \\
\text { and tricipital fold, BIA, } \\
\text { habitual intake questionnaire, } \\
\text { biochemical tests. }\end{array}$ & $\begin{array}{l}\text { The use of protease inhibitors does } \\
\text { not significantly interfere with } \\
\text { anthropometry, body composition } \\
\text { and dietary intake but is associated } \\
\text { with increased triglyceride and } \\
\text { LDL-c. }\end{array}$ \\
\hline $\begin{array}{l}\text { Diniz, et al., } \\
2011^{21} \text {. }\end{array}$ & \begin{tabular}{|l|}
196 children ( 95 \\
female, 101 male) \\
aged 0 to 12 years-old.
\end{tabular} & $\begin{array}{l}\text { Retrospective } \\
\text { cohort }\end{array}$ & $\begin{array}{l}\text { Anthropometric indices } \\
\text { (NCHS, 1977), clinical data, } \\
\text { biochemical tests. }\end{array}$ & $\begin{array}{l}\text { HAART resulted in a significant } \\
\text { increase in weight / age and height } \\
\text { / age indices. }\end{array}$ \\
\hline $\begin{array}{l}\text { Fausto et al., } \\
2011^{4} \text {. }\end{array}$ & $\begin{array}{l}33 \text { infants }(<3 \\
\text { months }) .\end{array}$ & Cohort & $\begin{array}{l}\text { Weight, height, } \\
\text { anthropometric indices } \\
\text { (WHO, 2007). }\end{array}$ & $\begin{array}{l}\text { There was an observed decrease } \\
\text { over time in the anthropometric } \\
\text { indices. }\end{array}$ \\
\hline $\begin{array}{l}\text { Carvalho et al., } \\
2009^{22} \text {. }\end{array}$ & $\begin{array}{l}120 \text { children of both } \\
\text { sexes, aged } 0-60 \\
\text { months. }\end{array}$ & $\begin{array}{l}\text { Retrospective } \\
\text { Cohort }\end{array}$ & $\begin{array}{l}\text { Anthropometric data, results } \\
\text { of laboratory tests and } \\
\text { clinical evaluations. }\end{array}$ & $\begin{array}{l}\text { Values of LT-CD4, Z-score of } \\
\text { weight / age and height / age } \\
\text { and median hemoglobin were } \\
\text { significantly lower in the group of } \\
\text { progressors. }\end{array}$ \\
\hline $\begin{array}{l}\text { Centeville et } \\
\text { al., } 2005^{23} \text {. }\end{array}$ & $\begin{array}{l}127 \text { children ( } 56 \\
\text { females, } 71 \text { males). }\end{array}$ & $\begin{array}{l}\text { Retrospective } \\
\text { longitudinal }\end{array}$ & $\begin{array}{l}\text { Anthropometric indices } \\
\text { (NCHS, 1977), birth weight, } \\
\text { age of onset of symptoms, } \\
\text { weight, height. }\end{array}$ & $\begin{array}{l}40.2 \% \text { of the children presented } \\
\text { malnutrition, } 31.5 \% \text { with height } \\
\text { impairment. }\end{array}$ \\
\hline $\begin{array}{l}\text { Leandro-Merhi } \\
\text { et al., } 2000^{1} \text {. }\end{array}$ & $\begin{array}{l}124 \text { ( } 71 \text { infected } \\
\text { and } 53 \text { uninfected } \\
\text { children) of both } \\
\text { sexes, aged } 3 \text { to } 21 \\
\text { months. }\end{array}$ & Longitudinal & $\begin{array}{l}\text { Gestational age at birth, } \\
\text { birth weight, weight and } \\
\text { height during the study } \\
\text { follow-up, anthropometric } \\
\text { indices (NCHS, 1977). }\end{array}$ & $\begin{array}{l}\text { Significant difference in weight } \\
\text { and height between groups. } \\
\text { Changes in growth arise soon after } \\
\text { birth. }\end{array}$ \\
\hline
\end{tabular}


Chart 4. Summary of articles on food intake in children and adolescents infected with HIV (Theme 4).

\begin{tabular}{|l|l|l|l|l|}
\hline Author, year & \multicolumn{1}{|c|}{ Target group } & Study design & \multicolumn{1}{|c|}{ Diagnostic Methods } & \multicolumn{1}{c|}{ Main results } \\
\hline $\begin{array}{l}\text { Tanaka et al., } \\
2015^{11} .\end{array}$ & $\begin{array}{l}88 \text { adolescents } \\
\text { aged } 10 \text { to } 19 \\
\text { years of both } \\
\text { sexes (40 males } \\
\text { and } 48 \text { females). }\end{array}$ & $\begin{array}{l}\text { Cross- } \\
\text { sectional } \\
\text { nested in a } \\
\text { cohort }\end{array}$ & $\begin{array}{l}\text { Weight, height, } \\
\text { waist circumference, } \\
\text { anthropometric index } \\
\text { (WHO, 2007), 24h } \\
\text { recall. }\end{array}$ & $\begin{array}{l}\text { Food pattern similar to that of } \\
\text { the general population (high } \\
\text { consumption of sugar, saturated } \\
\text { fat and sodium, and insufficient } \\
\text { intake of whole grains and fruits). }\end{array}$ \\
\hline
\end{tabular}

There is no restriction on the use of TDF in pregnancy, and it is even recommended for use in Brazilian pregnant women ${ }^{30}$. However, there is also no conviction as to the safety of its use during this period. Data from cohort studies have suggested a slight decrease in linear growth and cephalic perimeter in children up to one year of age a $^{29}$.

Drugs of the class of reverse transcriptase inhibitors, nucleotide analogs, can also cause low bone mineral density by raising lactic acid, a mechanism related to the decrease of calcium in bone trabeculae ${ }^{14}$.

Ritonavir (RTV), a drug of the IP class, is associated with alterations in gene expression, responsible for inducing local inflammatory activity and, consequently, reduction of osteoblast activity. Lopinavir (LPV/r) causes decreased gene expression and alkaline phosphatase enzyme activity in osteoblasts, thus decreasing calcium deposits and increased osteoclast activity ${ }^{7}$.

Insufficient intake of some minerals, such as magnesium, is associated with worsening of bone mass indicators; the decrease in the serum concentration of parathyroid hormone (PTH) and vitamin $\mathrm{D}$; the onset of inflammation with the production of pro-inflammatory cytokines; the reduction of osteoblast activity and the increase of osteoclast activity, resulting in greater bone resorption $^{8}$. It is pertinent to point out that prolonged exposure to efavirenz (EFZ) and PIs may result in changes in serum vitamin $\mathrm{D}^{14,18}$ concentrations.

Vitamin D insufficiency or deficiency is also associated with osteomalacia or acceleration of bone loss due to hyperparathyroidism. It is also known that ingestion of calcium and vitamin $\mathrm{D}$ is inadequate in Brazilian children and adolescents, which is far from the recommendation established by the Dietary Reference Intakes $(\mathrm{DRI})^{11,14,18}$.

Body composition, more specifically fat free mass, is associated with the bone formation process, positively influencing BMD. Weight, body mass index (BMI) and percentage of body fat $(\%$
GC) are also positively associated with BMD, especially in female adolescents $\mathrm{s}^{7,13,14,20}$.

Some components of HAART may cause metabolic complications, such as lipodystrophy, characterized by changes in body fat distribution $^{6,16}$. This disorder can be classified as central lipohypertrophy, which consists of the accumulation of fat in the region of the trunk and / or abdomen, breasts or posterior cervical region; or lipoatrophy, which consists of the reduction of adipose tissue in the face, lower and / or upper limbs and buttocks, both of which may occur in the same individual ${ }^{9,28}$.

Treatment with HAART and some chronic inflammatory diseases are responsible for stimulating stress at the cellular level, leading to adverse effects on lipid metabolism. This process leads to lipotoxicity and, consequently, changes in the distribution of body fat, and the more severe the infection, the more cellular stress may be present, with worsening of the condition ${ }^{10}$.

In other studies, HAART in the first years of life is positively associated with increased fat mass, fat free mass and number of cells, as well as increased weight and linear growth ${ }^{16,18,20}$.

Changes in body fat distribution are often observed in HIV-infected children and adolescents, and these changes are not always associated with inadequate BMI or nutritional status. However, when associated with other metabolic alterations such as dyslipidemia and increased visceral fat, frequently found in this age group, they are at increased risk for cardiovascular diseases ${ }^{9}$.

In addition, it should be emphasized that when there is presence of body changes in the individual, there are also changes in the perception of the body image, which can cause low adhesion to HAART and compromise the quality of life, especially in adolescents ${ }^{28}$.

The quantification of body fat percentage and fat free mass are not always free of inaccuracies, since changes in the distribution of these body compartments in children and adolescents are common, and also due to the limitation of noninvasive methods to predict these compartments ${ }^{9}$. 
There are a number of methods to measure body composition, including (1) plethysmography, (2) dual X-ray densitometry (DEXA) and (3) prediction equations, by means of skinfold thickness, being the latter the most used for children and adolescents, through the proposed equations Slaughter et al. ${ }^{31}$ and Lohman ${ }^{32}$. Methods (1) and (2) are expensive and require locations and collaborators appropriate for their execution; and method (3) because it is not invasive, it has been used more frequently, however, there are not many studies that validate the use of the equations mentioned above for use in children and adolescents infected with HIV ${ }^{28}$.

In this way, Lima et al. $^{28}$ proposed new equations for this population and demonstrated that the equations commonly used to estimate the percentage of body fat in children and adolescents without the infection presented poor performance when used in infected children and adolescents.

\section{Food Intake}

Brazilian studies indicate a high prevalence of metabolic disorders, such as dyslipidemia, in children and adolescents infected with HIV. AIDS is a chronic condition in which there is increased oxidative stress, leading to high endogenous consumption of antioxidant substances ${ }^{9,11,33}$.

Food intake observed in HIV-infected children and adolescents is similar to uninfected patients', generally inadequate, monotonous, high in sodium, sugar and saturated and trans fats; poor in fruits, milk and milk products, whole grains and fibers in general ${ }^{11,19}$.

Micronutrient deficiencies have been associated with increased mortality in HIV-infected persons and are directly related to the inadequate intake of these nutrients, which implies low serum quantification $^{33}$, impairing the immune system and worsening the patient's prognosis ${ }^{19}$.

Serum levels of vitamin E, under the reference values in young individuals, have been associated with retarded cognitive development and, like retinol and $\beta$-carotene deficiency, increase the incidence and severity of infections, functions of $\mathrm{T}$ and B cells. In turn, retinol may inhibit apoptosis of peripheral blood lymphocytes associated with HIV virus.

Monteiro et al. ${ }^{33}$ found low amounts of -carotene, vitamin $\mathrm{E}$ and retinol in blood samples from Latin American children living with HIV, which may be associated with low food intake of these micronutrients. Thus, Carmo et al. ${ }^{13}$ recommend micronutrient supplementation to address these deficiencies.
On the other hand, the World Health Organization $^{34}$ warns that the use of dietary and herbal supplements may alter the bioavailability, safety and efficacy of HAART, which may have important metabolic and nutritional implications.

Also, low levels of selenium and copper may influence the progression of HIV infection, and its deficiencies are associated with increased mortality regardless of CD4 $+\mathrm{T}$ cell counts. Zinc and copper are components of antioxidant enzymes, such as superoxide dismutase ( $\mathrm{CuZn}$ SOD), therefore deficiency of these minerals may negatively impact oxidative stress ${ }^{19}$.

Raiten et al. ${ }^{12}$ reiterate the importance and how determinant the nutritional interventions are in the weight gain and growth of HIV-infected children and adolescents, in the same way that Tanaka et al. ${ }^{11}$, positively associate the relationship between adequate feeding and strengthening of the immune system.

However, the scarcity of studies focusing on nutritional assessment and food intake in HIV-infected children and adolescents may be a limiting factor for care in this group ${ }^{11,28}$. In addition, studies have shown that HIV-infected children and adolescents may exhibit delayed sexual maturation, low weight and short stature for age, due to the use of HAART and possible dysfunction in the hypothalamic-pituitary-adrenal axis, altering growth rates ${ }^{5,15,17,18,35}$.

Tanaka et al. ${ }^{11}$ discuss that HIV-infected adolescents have similar food consumption to the adolescents of the general population, with a diet rich in sugar, saturated fat and sodium and low consumption of fruits and whole grains. Such behaviors require attention, as these adolescents are more predisposed to NCDs than others, especially hyperglycemia, insulin resistance, dyslipidemia and lipodystrophy syndrome ${ }^{10}$.

In the case of dyslipidemia, the use of lipid-lowering drugs should be evaluated with caution because, in addition to the few studies of this use in children and adolescents, the association of these with HAART may alter the concentration of anti-retrovirals and lead to an inadequate suppression of viral load or to higher toxicity ${ }^{9}$. Thus, counseling and dietary treatment are the best and safest means of preventing and / or treating dyslipidemia ${ }^{10}$.

Some studies have observed that even with the increased intake of macronutrients, HIV-infected children and adolescents remained with anthropometric indices within normality ${ }^{9}$, corroborating the fact that in these individuals, the energetic need is increased in relation to other groups. Thus, associated with the increase in energy 
supply, a proportional increase in the supply of micronutrients is also proposed, since these and the macronutrients are metabolically dependent, acting as cofactors in endogenous reactions ${ }^{12}$.

Despite the scientifically evidenced relevance, there is insufficient data for estimates of energy and micronutrient requirements that promote adequate growth and development in HIV-infected children and adolescents.

\section{Conclusion}

The access of HIV-infected children and adolescents to health services should be a continuous and integral part of the treatment, so that these and their families receive appropriate nutritional support, since this support associated with HAART may promote a better prognosis in the child and adolescent population infected with HIV. Howev- er, scientific studies focusing on nutritional management in this specific public are needed.

Therefore, the evaluation and monitoring of the quality of the diet are fundamental to guarantee the clinical and treatment conditions of these patients, as well as to prevent disorders due to the low consumption of nutrients.

\section{Collaborations}

LHA Gratão worked on the conception and design, analysis, interpretation of data and drafting the article; RJ Pereira and GNL Nascimento worked on design, analysis, interpretation of data and revising it critically. All the authors have approved of the version to be published.

\section{References}

1. Leandro-Merhi VA, Vilela MMS, Silva MN, Lopez FA, Barros Filho AA. Evaluation of nutritional status of infants infected with the human immunodeficiency vírus. São Paulo Med J 2000; 118(5):148-153.

2. Brasil. Ministério da Saúde (MS). Secretaria de Vigilância em Saúde. Departamento de Vigilância, Prevenção e Controle das Infecções Sexualmente Transmissíveis, do HIV/Aids e das Hepatites Virais. Boletim Epidemiológico HIV/Aids. Brasília: MS; 2015.

3. Brasil. Ministério da Saúde (MS). Secretaria de Vigilância em Saúde. Departamento de Vigilância, Prevenção e Controle das Infecções Sexualmente Transmissíveis, do HIV/Aids e das Hepatites Virais. Boletim Epidemiológico HIV/Aids. Brasília: MS; 2016.

4. Fausto MA, Mariângela Carneiro M, Antunes CMF, Colosimo EA, Pinto JA. Longitudinal anthropometric assessment of infants born to HIV-1-infected mothers, Belo Horizonte, Southeastern Brazil. Rev Saude Publica 2011; 45(4):652-660.

5. Cardoso CAA, Pinto JA, Candiani TMS, Carvalho IR, Linhares RM, Goulart EMA. The impact of highly active antiretroviral therapy on the survival of vertically HIV-infected children and adolescents in Belo Horizonte, Brazil. Mem Inst Oswaldo Cruz 2012; 107(4):532-538.
6. Contri PV, Berchielli EM, Tremeschin MH, Negrini BVM, Salomão RG, Monteiro JP. Nutritional status and lipid profile of HIV-positive children and adolescents using antiretroviral therapy. Clinics 2011; 66(6):997-1002.

7. Lima LRA, Silva RCR, Giulianoc ICB, Sakunod T, Sérgio M. Brincase, Carvalho AP. Bone mass in children and adolescentes infected with human immunodefciency virus. J Pediatr 2013; 89(1):91-99.

8. Palchetti CZ, Szejnfeld VL, Succi RCM, Patin RV, Teixeira PF, Machado DM, Oliveira FLC. Impaired bone mineral accrual in prepubertal HIV-infected children: a cohort study. Braz J Infect Dis 2015; 19(6):623-630.

9. Werner ML, Pone MV, Fonseca VM, Chaves CR. Lipodystrophy syndrome and cardiovascular risk factors in children and adolescents infected with HIV/AIDS receiving highly active antiretroviral therapy. J Pediatr (Rio J) 2010; 86(1):27-32.

10. Papi L, Menezes ACGB, Rocha H, Abreu TF, Oliveira RH, Frota ACC, Evangelista LA, Hofer CB. Prevalence of lipodystrophy and risk factors for dyslipidemia in HIV-infected children in Brazil. Braz J Infect Dis 2014; 18(4):394-399.

11. Tanaka LF, Latorre MR, Silva AM, Konstantyner TC, Mendes EC, Marques HH. Poor diet quality among Brazilian adolescents with HIV/AIDS. J Pediatr (Rio J) 2015; 91(2):152-159. 
12. Raiten DJ, Mulligan K, Papathakis P, Wanke C. Executive summary - Nutritional care of HIV-infected adolescents and adults, including pregnant and lactating women: What do we know, What can we do, and Where do we go from here? Am J Clin Nutr 2011; 94(6):1667S-76S.

13. Carmo FB, Terreri MT, Succi RCM, Beltrão SV, Gouvea AFTB, Paulino ERC, Machado DM. Bone mineral density and vitamin $\mathrm{D}$ concentration: the challenges in taking care of children and adolescents infected with HIV. Braz J Infect Dis 2017; 21(3):270-275.

14. Schtscherbyna A, Pinheiro MFMC, Mendonc LMC, Gouveia C, Luiz RR, Machado ES, Farias MLF. Factors associated with low bone mineral density in a Brazilian cohort of vertically HIV-infected adolescents. Inter J Infect Dis 2012; 16(12):e872-e878.

15. Palchetti CZ, Patin RV, Gouvêa AFTB, Szejnfeld VL, Succi RCM, Oliveira FLC. Body composition and lipodystrophy in prepubertal HIV-infected children. Braz J Infect Dis 2013; 17(1):1-6.

16. Sarni ROS, Souza FIS, Battistini TRB, Pitta TS, Fernandes AP, Tardini PC, Fonseca FLA, Santos VP, Lopez FA. Lipodystrophy in children and adolescentes with acquired immunodefciency syndrome and its relationship with the antiretroviral therapy employed. $J$ Pediatr (Rio J) 2009; 85(4):329-334.

17. Lima LRA, Petroski EL, Moreno YMF, Silva DAS, Trindade EBMS, Carvalho AP, Back IC. Dyslipidemia, chronic inflammation, and subclinical atherosclerosis in children and adolescents infected with HIV: The PositHIVe Health Study. PLoS ONE 2018; 13(1):e0190785.

18. Schtscherbyna A, Gouveia C, Pinheiro MFMC, Luiz RR, Farias MLF, Machado ES. Vitamin D status in a Brazilian cohort of adolescents and young adults with perinatally acquired human immunodeficiency virus infection. Mem Inst Oswaldo Cruz 2016; 111(2):128133.

19. Pugliese C, Patin RV,Cecilia Zanin Palchetti CZ, Claudio CC, Gouvêa AFTB, Succi RCM, Amancio OMS, Cozzolino SMF, Oliveira FLC. Assessment of antioxidants status and superoxide dismutase activity in HIV-infected children. Braz J Infect Dis 2014; 18(5):481486.

20. Bassichetto KC, Bergamasch DP, Frainer DES, Garcia VRS, Trovões EAT. Weight and height of people living with HIV/AIDS attended by the Brazilian National Health System. Rev Bras Epidemiol 2013; 16(3):622632.

21. Diniz LMO, Maia MMM, Camargos LS, Amara LC, Goulart EMA, Pinto JA. Impacto da terapia antirretroviral combinada no crescimento e nas taxas de hospitalização de crianças infectadas pelo HIV. J Pediatr (Rio J) 2011; 87(2):131-137.

22. Carvalho IR, Pinto JA, Cardoso CA, Candiani TM, Kakehasi FM. Evaluation of hematological, virologic and anthropometric parameters as progression markers in HIV-1 infected children. J Pediatr (Rio J) 2009; 85(2):149-156.

23. Centeville M, Morcillo AM, Filho AAB,Silva MTN, Dalbo AA, Toro C, Vilela MMS. Lack of association between nutritional status and change in clinical category among HIV infected children in Brazil. Sao Paulo Med J 2005; 123(2):62-65.
24. Brasil. Ministério da Saúde (MS). Secretaria de Atenção à Saúde. Guia alimentar para a população brasileira: promovendo a alimentação saudável. Brasília: MS; 2008.

25. Brasil. Ministério da Saúde (MS). Secretaria de Atenção à Saúde. Departamento de Atenção Básica. Guia alimentar para a população brasileira. 2a ed. Brasília: MS; 2014.

26. Cruz MLS, Hance LF, Korelitz J, Aguilar A, Byrne J, Serchuck LK, Hazra R, Worrell C. Characteristics of HIV infected adolescents in Latin America: results from the NISDI pediatric study. J Trop Pediatr 2011; 57(3):165-172.

27. Evans C, Chasekwa B, Ntozini R, Humphrey JH, Prendergast AJ. Head circumferences of children born to HIV-infected and HIV-uninfected mothers in Zimbabwe during the preantiretroviral therapy era. AIDS 2016; 30(15):2323-2328.

28. Lima LRA, Martins PC, Junior CASA, Castro JAC, Silva DAS, Petroski EL. Are traditional body fat equations and anthropometry valid to estimate body fat in children and adolescents living with HIV? Braz J Infect Dis 2017; 21(4):448-456.

29. Osorio LE, Boechat MI, Mirochnick M, Kumwenda N, Kreitchmann R, Emel L, Pinto J, Joao E, Santos B, Swenson M, George K, Sato P, Mofenson L, Nielsen-Saines K. Bone age and mineral density assessments using plain roentgenograms in tenofovir exposed infants in Malawi and Brazil enrolled in HIV prevention trials network 057. Pediatr Infect Dis J 2017; 36(2):184-188.

30. Brasil. Ministério da Saúde (MS). Secretaria de Vigilância em Saúde. Departamento de Vigilância, Prevenção e Controle das Infecções Sexualmente Transmissíveis, do HIV/Aids e das Hepatites Virais. Protocolo Clínico e Diretrizes Terapêuticas para manejo da infecção pelo HIV em adultos. Brasília: MS; 2017.

31. Slaughter MH, Lohman TG, Boileau R, Horswill CA, Stillman RJ, Van Loan MD, Bemben DA. Skinfold equations for estimation of body fatness in children and youth. Hum Biol 1988; 60(5):9-23.

32. Lohman TG. Assessment of body composition in children. Pediatr Exerc Sci 1989; 1(1):19-30.

33. Monteiro JP, Freimanis-Hance L, Faria LB, Mussi-Pinhata MM, Korelitz J, Vannucchi H, Queiroz W, Succi RCM, Hazra R. Both HIV-infected and HIV-exposed uninfected children living in Brazil, Argentina and Mexico have similar rates of low concentrations of retinol, -carotene and vitamin E. Nutr Res 2009; 29(10):716-722.

34. World Health Organizations (WHO). Interim WHO clinical staging of HIV/AIDS case definitions for surveillance. Geneva. Switzerland: WHO; 2005.

35. Moolasart V, Chottanapund S, Ausavapipit J, Ampornareekul S. Prevalence and risk factors of malnutrition among HIV-Infected children aged 2-18 Years: A cross-sectional study. Pediatric Infect Dis 2017; 2:36.

Article submitted 22/05/2018

Approved 05/06/2019

Final version submitted 07/06/2019

Chief editors: Romeu Gomes, Antônio Augusto Moura da Silva 